\title{
Isolation of $\mathrm{Pd}$ atoms by $\mathrm{Cu}$ for semi-hydrogenation of acetylene: Effects of Cu loading
}

\author{
Guangxian Pei a,b, Xiaoyan Liu a,*, Mengqian Chai a,b, Aiqin Wang a, Tao Zhang a,\# \\ a State Key Laboratory of Catalysis, Collaborative Innovation Center of Chemistry for Energy Materials (iChEM), Dalian Institute of Chemical Physics, \\ Chinese Academy of Sciences, Dalian 116023, Liaoning, China \\ b University of Chinese Academy of Sciences, Beijing 100049, China
}

\section{A R T I C L E I N F}

\section{Article history:}

Received 31 March 2017

Accepted 30 April 2017

Published 5 September 2017

\section{Keywords:}

Copper

Palladium

Single-atom catalyst

X-ray absorption spectroscopy

Acetylene hydrogenation

Excess ethylene

\begin{abstract}
A B S T R A C T
Cu-alloyed Pd single-atom catalysts exhibit excellent catalytic performance for the semi-hydrogenation of acetylene; however, the limit of the $\mathrm{Cu} / \mathrm{Pd}$ atomic ratio for forming the alloyed Pd single-atom catalyst is ambiguous. Herein, silica-supported $\mathrm{Cu}-\mathrm{Pd}$ bimetallic catalysts with fixed $\mathrm{Pd}$ content and varied $\mathrm{Cu}$ loadings were synthesized using an incipient wetness co-impregnation method. The X-ray absorption spectroscopy results indicated that $\mathrm{Pd}$ formed an alloy with $\mathrm{Cu}$ after reduction at $250{ }^{\circ} \mathrm{C}$ and that the $\mathrm{Pd}$ atoms were completely isolated by $\mathrm{Cu}$ for $\mathrm{Cu} / \mathrm{Pd}$ atomic ratios $\geq 40 / 1$. Notably, increasing the reduction temperature from 250 to $400{ }^{\circ} \mathrm{C}$ hardly affected the catalytic performances of the $\mathrm{Cu}-\mathrm{Pd} / \mathrm{SiO}_{2}$ catalysts. This finding can be attributed to the similar chemical environments of Pd demonstrated by the X-ray absorption spectroscopy results.
\end{abstract}

(C) 2017, Dalian Institute of Chemical Physics, Chinese Academy of Sciences. Published by Elsevier B.V. All rights reserved.

\section{Introduction}

Supported nanocatalysts for various important reactions always contain noble metals or alloys. Although they are active under modest reaction conditions, these catalysts are always not selective toward the desired products. In addition, the active sites always cannot be efficiently used. Recently, single-atom catalysts (SACs) with atomic efficiency of the active sites have drawn extensive attention [1-9]. Among the SACs, alloyed SACs with different geometric environments and electronic structures can achieve excellent selectivity toward the target products [10-15]. For example, Sykes et al. [10-12] found that the alloying of $\mathrm{Pd}$ or Pt single atoms with $\mathrm{Cu}$ promoted the dissociation of $\mathrm{H}_{2}$, thus making the alloyed $\mathrm{Pd}$ or $\mathrm{Pt}$ single atoms efficient for selective hydrogenation reactions [10-12]. Zhang et al. $[13,14]$ anchored Au single atom onto Pd cluster using a colloidal method followed by galvanic replacement, resulting in greatly enhanced catalytic performance for aerobic glucose oxidation compared with the performances of the corresponding monometallic catalysts. In addition, the Au-alloyed Pd SAC obtained by ion exchange on the resin support was efficient and durable for the Ullman reaction of aryl chlorides in water [15].

Selective hydrogenation of acetylene to ethylene in an eth-

\footnotetext{
* Corresponding author. Tel: +86-411-84379416; Fax: +86-411-84685940; E-mail: xyliu2003@dicp.ac.cn

\# Corresponding author. Tel: +86-411-84379015; Fax: +86-411-84691570; E-mail: taozhang@dicp.ac.cn

This work was supported by the National Natural Science Foundation of China $(21303194,21476227,21522608$ and 21690084), Youth Innovation Promotion Association of the Chinese Academy of Sciences (2014163), the National Key Projects for Fundamental Research and Development of China (2016YFA0202801), the Strategic Priority Research Program of the Chinese Academy of Sciences (XDB17020100), and the department of science and technology of Liaoning province under contract of 2015020086-101.

DOI: 10.1016/S1872-2067(17)62847-X | http://www.sciencedirect.com/science/journal/18722067 | Chin. J. Catal., Vol. 38, No. 9, September 2017
} 
ylene-rich stream is an important process in industry. The ethylene used to produce polyethylene is mainly produced by the cracking of naphtha. During this process, a small amount of acetylene $(\sim 1 \%)$ is produced, which is poisonous to the catalysts for the polymerization. Therefore, reducing the acetylene concentration in the feed gas to an acceptable level is highly desirable [16-19]. Selective hydrogenation of acetylene to ethylene is the preferred method to eliminate the acetylene. Monometallic Pd catalyst displays high acetylene conversion for this process $[20,21]$; however, its selectivity to ethylene is extremely low. Great efforts have been made to improve the ethylene selectivity over Pd-based catalysts using, for example, the modification of Pd by other elements $(\mathrm{Au}, \mathrm{Ag}, \mathrm{Cu}, \mathrm{Ga}, \mathrm{Si}, \mathrm{C}$, S) [22-28]. Although improved ethylene selectivity has been achieved, the results are not satisfactory, especially with increased reaction temperature, a large amount of ethylene in the feed gas is simultaneously hydrogenated to ethane. Moreover, most of the promoters will block the surface of the Pd nanoparticles, resulting in a waste of the active sites. Therefore, the design of a type of novel catalyst that overcomes these deficiencies is highly desirable.

In our previous work, silica-supported Group-IB-metal-alloyed Pd SACs were synthesized and utilized for the selective hydrogenation of acetylene in an ethylene-rich stream [29-31]. Compared with the monometallic $\mathrm{Pd} / \mathrm{SiO}_{2}$ catalyst, the Group-IB-metal-alloyed Pd SACs significantly improved the ethylene selectivity at high acetylene conversions. In particular, for the $\mathrm{Cu}$-alloyed $\mathrm{Pd} \mathrm{SAC}$, complete acetylene conversion was accompanied by $\sim 85 \%$ selectivity to ethylene [31]. Although the Pd atoms could be isolated and efficiently used when the $\mathrm{Cu} / \mathrm{Pd}$ atomic ratio was $160 / 1$, an excess of the group IB metal would be employed because of their relatively high loadings. Determination of the optimized amount of both the group IB metal and Pd is thus necessary to reduce the costs of the catalysts.

In this work, by applying a fixed Pd content and varied $\mathrm{Cu}$ loadings, we synthesized a series of $\mathrm{Cu}$-Pd bimetallic catalysts on silica supports using an incipient wetness co-impregnation method. The interaction between $\mathrm{Pd}$ and $\mathrm{Cu}$ was analyzed using X-ray diffraction (XRD) and temperature-programmed reduction (TPR) analyses. In addition, the chemical environment of the Pd atoms in all the samples was analyzed using X-ray absorption spectroscopy (XAS). Based on the results of these analyses, the atomic ratio of $\mathrm{Cu} / \mathrm{Pd}$ for the formation of $\mathrm{Cu}$-alloyed Pd SAC was optimized. Finally, the catalytic performances of the bimetallic catalysts for the semi-hydrogenation of acetylene in an ethylene-rich stream after reduction at different temperatures were evaluated.

\section{Experimental}

\subsection{Catalyst preparation}

$\mathrm{Cu}-\mathrm{Pd} / \mathrm{SiO}_{2}$ catalysts with different $\mathrm{Cu} / \mathrm{Pd}$ atomic ratios were synthesized using the incipient wetness co-impregnation method. First, silica gel (Qingdao Ocean Chemical Plant) with a Brunauer-Emmett-Teller (BET) surface area of $463 \mathrm{~m}^{2} \cdot \mathrm{g}^{-1}$ was impregnated with a mixture of $\mathrm{Cu}\left(\mathrm{NO}_{3}\right)_{2} \cdot 3 \mathrm{H}_{2} \mathrm{O}$ and $\mathrm{Pd}\left(\mathrm{NO}_{3}\right)_{2}$ solution to achieve a nominal Pd loading of $523 \mathrm{ppm}$ and varied $\mathrm{Cu} / \mathrm{Pd}$ atomic ratios. The samples were subsequently dried at $80{ }^{\circ} \mathrm{C}$ for $10 \mathrm{~h}$ and calcined in air at $400{ }^{\circ} \mathrm{C}$ for $2 \mathrm{~h}$. The as-prepared samples are denoted as $\mathrm{Cu}_{x} \mathrm{Pd} / \mathrm{SiO}_{2}$ with $x$ referring to the $\mathrm{Cu} / \mathrm{Pd}$ atomic ratio. Monometallic $\mathrm{Cu} / \mathrm{SiO}_{2}$ and $\mathrm{Pd} / \mathrm{SiO}_{2}$ catalysts, with similar $\mathrm{Cu}$ or Pd loading to those of the $\mathrm{Cu}_{160} \mathrm{Pd} / \mathrm{SiO}_{2}$ catalyst, were also prepared using the same method.

\subsection{Catalyst characterization}

The actual metal loadings of all the as-prepared samples were determined using inductively coupled plasma spectrometry (ICP-AES; Thermo IRIS Intrepid II XSP). Before the measurement, the samples were first treated with HF to remove the silica support, followed by treatment with aqua regia and dilution to the desired concentration.

TPR experiments were performed on a Micromeritics AutoChem II 2920 automated characterization system. First, approximately $170 \mathrm{mg}$ of the calcined sample was loaded into a U-shaped quartz tube and pretreated with Ar for $10 \mathrm{~min}$. The gas flow was then switched to a gas mixture of $10 \mathrm{vol} \% \mathrm{H}_{2} / \mathrm{Ar}$, and the sample was heated to $500{ }^{\circ} \mathrm{C}$ at $10^{\circ} \mathrm{C} \cdot \mathrm{min}^{-1}$.

XRD patterns were obtained using a PANalytical PW3040/60 X'Pert Pro Super diffractometer, which was operated at $40 \mathrm{kV}$ and $40 \mathrm{~mA}$ and equipped with a $\mathrm{Cu} K \alpha$ radiation source $(\lambda=0.15432 \mathrm{~nm})$. The scanning angle $(2 \theta)$ ranged from $10^{\circ}$ to $80^{\circ}$. Before the experiment, all the samples were reduced at $250{ }^{\circ} \mathrm{C}$ for $1 \mathrm{~h}$.

XAS spectra (including the X-ray absorption near-edge structure (XANES) and extended X-ray absorption fine structure (EXAFS)) at the Pd K-edge were recorded at the BL14W1 beamline of the Shanghai Synchrotron Radiation Facility (SSRF), Shanghai Institute of Applied Physics (SINAP), China [32]. Energy selection was performed using a double Si (311)-crystal monochromator. Energy calibration was performed using a Pd foil. The spectra were collected at room temperature under the fluorescence mode using a solid-state detector. Before the experiments, the samples were reduced at 250 or $400{ }^{\circ} \mathrm{C}$ for $1 \mathrm{~h}$ and then purged by He for another 10 min. After cooling to room temperature, the reactor was evacuated, and the samples were transferred to a glovebox. The samples were then sealed in Kapton films in the glovebox. Data fitting was performed using the Athena software package.

\subsection{Catalytic performance evaluation}

Selective hydrogenation of acetylene in an ethylene-rich stream was performed in a quartz reactor. Before the experiments, $30 \mathrm{mg}$ of the sample was pretreated with flowing 80 vol\% $\mathrm{H}_{2} / \mathrm{He}\left(20 \mathrm{~mL} \cdot \mathrm{min}^{-1}\right)$ at 250 or $400{ }^{\circ} \mathrm{C}$ for $1 \mathrm{~h}$ and then purged using $\mathrm{He}\left(20 \mathrm{~mL} \cdot \mathrm{min}^{-1}\right)$ at the same temperature. After cooling to room temperature, a gas mixture with a space velocity of $60,000 \mathrm{~mL} \cdot \mathrm{h}^{-1} \cdot \mathrm{g}^{-1}$ was introduced into the quartz reactor under the following simulated front-end hydrogenation conditions: 1.0 vol\% $\mathrm{C}_{2} \mathrm{H}_{2}, 20.0$ vol\% $\mathrm{H}_{2}$, and 20.0 vol\% $\mathrm{C}_{2} \mathrm{H}_{4}$ bal- 
anced with $\mathrm{He}$. The purities of the gases were as follows: $\mathrm{H}_{2}$ (UHP, 99.999\%), He (UHP, 99.999\%), $\mathrm{C}_{2} \mathrm{H}_{2}$ and $\mathrm{C}_{2} \mathrm{H}_{4}$ (mixture of 4.76 vol\% $\mathrm{C}_{2} \mathrm{H}_{2}$ in $\mathrm{C}_{2} \mathrm{H}_{4}$ with 50 ppm $\mathrm{C}_{2} \mathrm{H}_{6}$ and $10 \mathrm{ppm} \mathrm{CH}_{4}$ impurity from Dalian Special Gases Co., Ltd.). Mass flow controllers were employed to control all the gas flows. The reaction temperature was held constant for 25 min before ramping to the next temperature point. The gas components from both the microreactor inlet and outlet were analyzed using on-line gas chromatography (GC, Agilent Technologies 6890N) and a flame ionization detector.

Consistent with our previous studies [29-31,33-35], the only $\mathrm{C} 2$ products detected by GC were $\mathrm{C}_{2} \mathrm{H}_{4}$ and $\mathrm{C}_{2} \mathrm{H}_{6}$. Because of the short contact time, the oligomer amount formed during the hydrogenation process was negligible. Based on the volume ratios of the inlet and outlet gas composition, the following equations were used to calculate the conversion and selectivity:

Conversion $=\left(\mathrm{C}_{2} \mathrm{H}_{2}\right.$ (feed) $\left.-\mathrm{C}_{2} \mathrm{H}_{2}\right) / \mathrm{C}_{2} \mathrm{H}_{2}$ (feed) $\times 100 \%$ (1)

Selectivity $=\left[1-\left(\mathrm{C}_{2} \mathrm{H}_{2}-\mathrm{C}_{2} \mathrm{H}_{6}(\right.\right.$ feed $\left.)\right) /\left(\mathrm{C}_{2} \mathrm{H}_{2}\right.$ (feed) $\left.\left.-\mathrm{C}_{2} \mathrm{H}_{2}\right)\right]$

$$
\times 100 \% \text {. }
$$

\section{Results and discussion}

\subsection{Reducibility and crystallinity}

TPR characterization was used to analyze the reducibility of the catalysts. Fig. 1 presents the TPR profiles of the $\mathrm{Cu}-\mathrm{Pd} / \mathrm{SiO}_{2}$ bimetallic catalysts with different $\mathrm{Cu} / \mathrm{Pd}$ atomic ratios (Table 1). The reduction peak for the monometallic $\mathrm{Pd} / \mathrm{SiO}_{2}$ catalyst was hardly detectable, which might be due to the low Pd content. However, the reported reduction temperature for the $\mathrm{Pd} / \mathrm{SiO}_{2}$ catalyst is approximately $100{ }^{\circ} \mathrm{C}$ [36]. A broad reduction peak from $200{ }^{\circ} \mathrm{C}$ to higher than $350{ }^{\circ} \mathrm{C}$ was observed for the monometallic $\mathrm{Cu} / \mathrm{SiO}_{2}$ catalyst. The reduction peaks appeared for both $\mathrm{CuO}_{x}$ and $\mathrm{PdO}$ over the catalysts with relatively high $\mathrm{Cu}$ loadings. For the $\mathrm{Cu}_{160} \mathrm{Pd} / \mathrm{SiO}_{2}$ catalyst, reduction peaks at approximately $100{ }^{\circ} \mathrm{C}$ and from 150 to $\sim 300{ }^{\circ} \mathrm{C}$ were detected. The former was attributed to the reduction of PdO [36], and the latter was attributed to the reduction of $\mathrm{CuO}_{x}$ [37]. With decreased $\mathrm{Cu}$ loading, the reduction peak for PdO shifted slightly to lower temperature, similar to the reduction temperature of the reported monometallic $\mathrm{Pd} / \mathrm{SiO}_{2}$ catalyst [36]. However, the reduction peaks of $\mathrm{CuO}_{x}$ shifted to below $250{ }^{\circ} \mathrm{C}$ for the $\mathrm{Cu}_{40} \mathrm{Pd} / \mathrm{SiO}_{2}$ and $\mathrm{Cu}_{12} \mathrm{Pd} / \mathrm{SiO}_{2}$ catalysts, indicating the promoted reduction of $\mathrm{CuO}_{x}$, which could be attributed to the

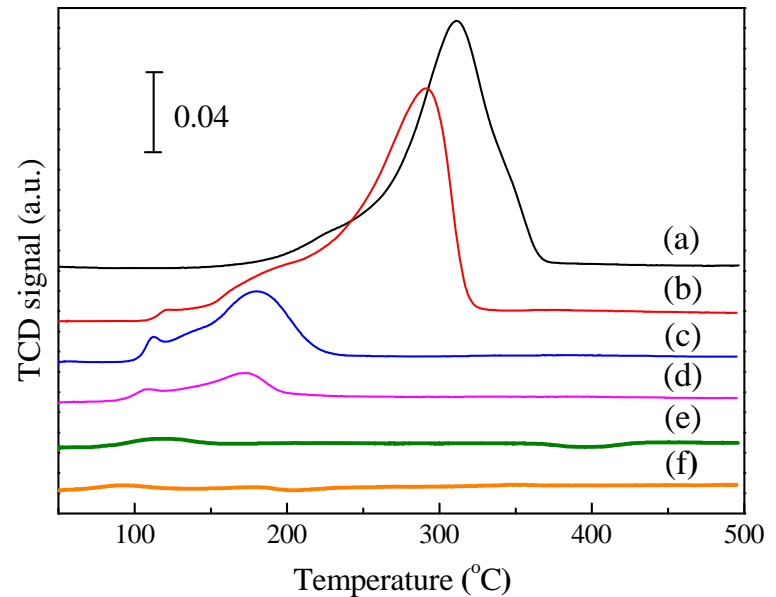

Fig. 1. TPR profiles of the $\mathrm{Cu} / \mathrm{SiO}_{2}(\mathrm{a}), \mathrm{Cu}_{160} \mathrm{Pd} / \mathrm{SiO}_{2}$ (b), $\mathrm{Cu}_{40} \mathrm{Pd} / \mathrm{SiO}_{2}$ (c), $\mathrm{Cu}_{12} \mathrm{Pd} / \mathrm{SiO}_{2}(\mathrm{~d}), \mathrm{Cu}_{5} \mathrm{Pd} / \mathrm{SiO}_{2}(\mathrm{e})$, and $\mathrm{Pd} / \mathrm{SiO}_{2}$ (f) catalysts.

decreased $\mathrm{Cu}$ particle sizes or loadings. In addition, the formation of the $\mathrm{Cu}-\mathrm{Pd}$ alloy also promoted the reduction of $\mathrm{CuO}_{x}$. Similar to our previous findings, the reduction temperatures of $\mathrm{CuO}_{x}$ in these catalysts were lower than that of the monometallic $\mathrm{Cu} / \mathrm{SiO}_{2}$ catalyst, which could be attributed to the spillover of hydrogen from $\mathrm{Pd}$, thus promoting the reduction of $\mathrm{CuO}_{x}$ [31]. Only one peak from 100 to $150{ }^{\circ} \mathrm{C}$ could be detected over the $\mathrm{Cu}_{5} \mathrm{Pd} / \mathrm{SiO}_{2}$ catalyst, which may be attributed to the reduction of both $\mathrm{CuO}_{x}$ and PdO. All these results suggest the interaction between $\mathrm{Cu}$ and $\mathrm{Pd}$, which may induce different reducibilities over all these samples.

The structures of the $\mathrm{Cu}-\mathrm{Pd} / \mathrm{SiO}_{2}$ bimetallic catalysts with fixed $\mathrm{Pd}$ content and varied $\mathrm{Cu}$ loadings were analyzed using XRD. As observed in Fig. 2, the $\mathrm{Cu}_{160} \mathrm{Pd} / \mathrm{SiO}_{2}$ catalyst with the highest $\mathrm{Cu}$ loading showed clear diffraction peaks at $43.3^{\circ}$, $50.4^{\circ}$, and $74.1^{\circ}$, which could be attributed to the crystal planes of $\mathrm{Cu}(111),(200)$, and (220), respectively [31]. According to the Scherrer equation, the corresponding particle size of the $\mathrm{Cu} 160 \mathrm{Pd} / \mathrm{SiO}_{2}$ catalyst was $40.7 \mathrm{~nm}$. With decreased $\mathrm{Cu}$ loading, the intensity of the diffraction peaks sharply decreased (Fig. 2). For the $\mathrm{Cu}_{40} \mathrm{Pd} / \mathrm{SiO}_{2}$ catalyst, only the diffraction peak of $\mathrm{Cu}$ (111) could be detected. Further decreasing the $\mathrm{Cu}$ loading resulted in much smaller bimetallic particle sizes, which could not be detected by XRD. No Pd diffraction peak was detected over any of the samples, mainly because the Pd content was too low to be detected by XRD. The detailed chemical environment

Table 1

Elemental analysis of the $\mathrm{Cu}-\mathrm{Pd} / \mathrm{SiO}_{2}$ bimetallic catalysts.

\begin{tabular}{|c|c|c|c|c|c|c|}
\hline \multirow{2}{*}{ Entry } & \multirow{2}{*}{ Catalyst } & \multirow{2}{*}{$\begin{array}{c}\mathrm{Cu}: \mathrm{Pd} \\
\text { (atomic ratio) }\end{array}$} & \multicolumn{2}{|c|}{ Nominal loading } & \multicolumn{2}{|c|}{ Actual loading a } \\
\hline & & & $\mathrm{Cu}(\mathrm{wt} \%)$ & $\mathrm{Pd}(\mathrm{ppm})$ & $\mathrm{Cu}(\mathrm{wt} \%)$ & $\mathrm{Pd}(\mathrm{ppm})$ \\
\hline 1 & $\mathrm{Cu}_{160} \mathrm{Pd} / \mathrm{SiO}_{2}$ & 160 & 5 & 523 & 4.96 & 494 \\
\hline 2 & $\mathrm{Cu}_{40} \mathrm{Pd} / \mathrm{SiO}_{2}$ & 40 & 1.25 & 523 & 1.31 & 583 \\
\hline 3 & $\mathrm{Cu}_{12} \mathrm{Pd} / \mathrm{SiO}_{2}$ & 12 & 0.38 & 523 & 0.38 & 552 \\
\hline 4 & $\mathrm{Cu}_{5} \mathrm{Pd} / \mathrm{SiO}_{2}$ & 5 & 0.16 & 523 & 0.16 & 648 \\
\hline 5 & $\mathrm{Cu} / \mathrm{SiO}_{2}$ & - & 5 & 0 & 5.28 & - \\
\hline 6 & $\mathrm{Pd} / \mathrm{SiO}_{2}$ & 0 & 0 & 523 & - & 448 \\
\hline
\end{tabular}

a Determined by ICP-AES. 


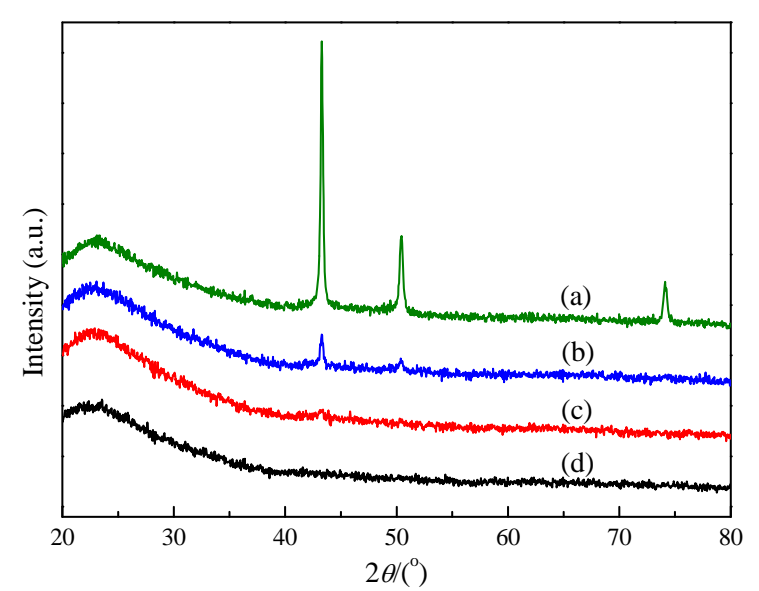

Fig. 2. XRD patterns of the $\mathrm{Cu}_{160} \mathrm{Pd} / \mathrm{SiO}_{2}$ (a), $\mathrm{Cu}_{40} \mathrm{Pd} / \mathrm{SiO}_{2}$ (b), $\mathrm{Cu}_{12} \mathrm{Pd} / \mathrm{SiO}_{2}$ (c), and $\mathrm{Cu}_{5} \mathrm{Pd} / \mathrm{SiO}_{2}$ (d) catalysts after reduction at $250^{\circ} \mathrm{C}$.

of the Pd atoms will be discussed in the following section.

\subsection{Isolation of Pd atoms}

XAS is a powerful technique that can determine the chemical environment of a selected element, even though the loading of Pd was at the ppm level. To analyze the chemical environment of the Pd atoms in different catalysts, XAS analyses were performed over the $\mathrm{Cu}-\mathrm{Pd} / \mathrm{SiO}_{2}$ bimetallic catalysts with varied Cu loadings.

\subsubsection{Effect of Cu loading}

In our previous work, with a Pd content of $494 \mathrm{ppm}$ and $\mathrm{Cu} / \mathrm{Pd}$ atomic ratio of $160 / 1$ (corresponding to a $\mathrm{CuPd} 0.006 / \mathrm{SiO}_{2}$ catalyst), the EXAFS data fitting result of Pd showed only $\mathrm{Pd}-\mathrm{Cu}$ coordination in the catalyst, indicating the formation of a Cu-alloyed Pd SAC [31]. In this work, to determine the chemical environment of the $\mathrm{Pd}$ atoms in the $\mathrm{Cu}-\mathrm{Pd} / \mathrm{SiO}_{2}$ bimetallic catalysts with different $\mathrm{Cu}$ loadings, EXAFS characterization was first performed over the samples reduced at $250{ }^{\circ} \mathrm{C}$. As ob-
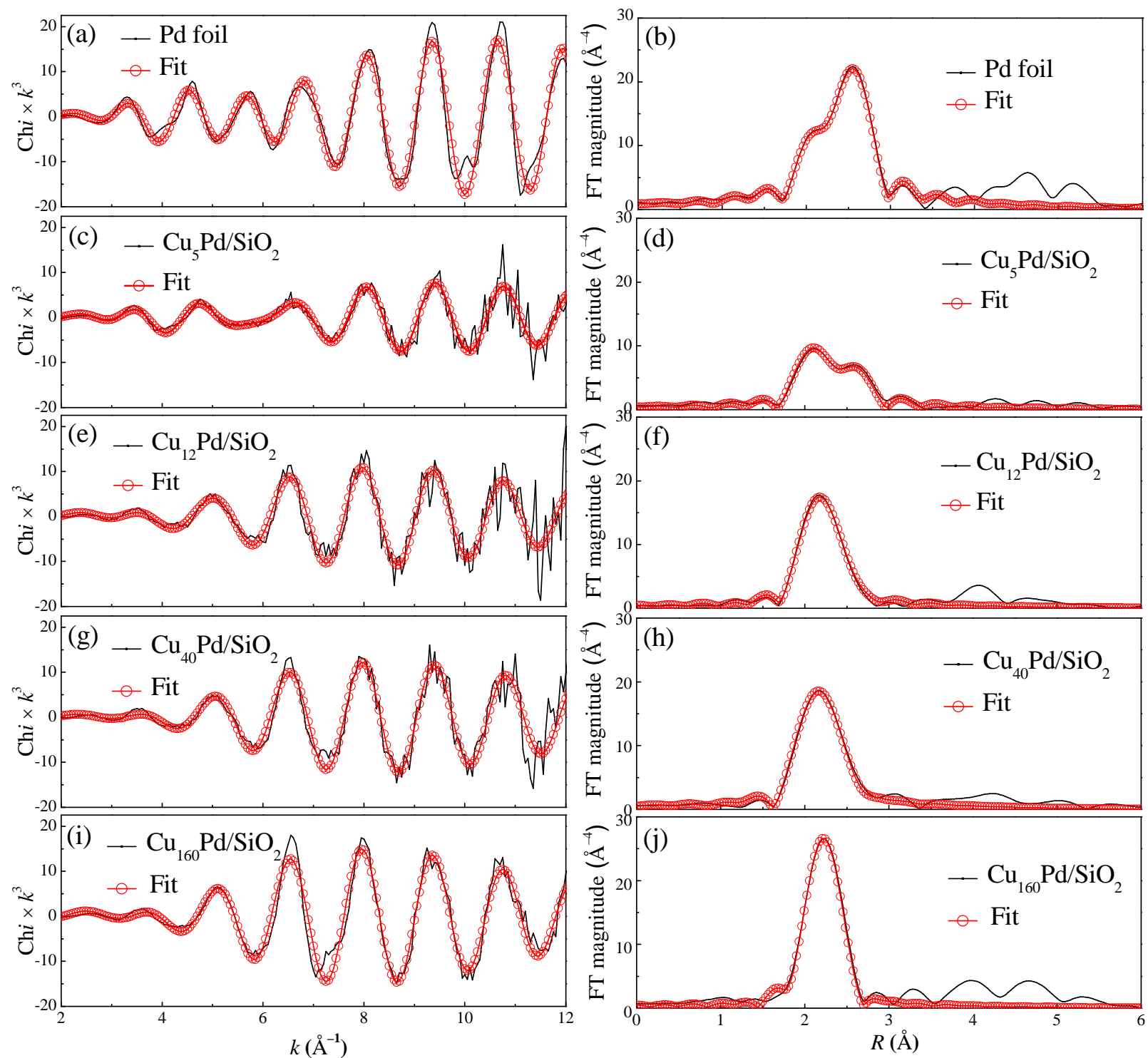

Fig. 3. $k^{3}$-weighted EXAFS spectra in $k$-space (a, c, e, g, i) and corresponding Fourier transform spectra in $R$-space (without phase correction) (b, d, f, h, j) of $\mathrm{Pd}$ foil $(\mathrm{a}, \mathrm{b})$ and $\mathrm{Cu}_{5} \mathrm{Pd} / \mathrm{SiO}_{2}(\mathrm{c}, \mathrm{d}), \mathrm{Cu}_{12} \mathrm{Pd} / \mathrm{SiO}_{2}(\mathrm{e}, \mathrm{f}), \mathrm{Cu}_{40} \mathrm{Pd} / \mathrm{SiO}_{2}(\mathrm{~g}, \mathrm{~h})$, and $\mathrm{Cu}_{160} \mathrm{Pd} / \mathrm{SiO}_{2}(\mathrm{i}, \mathrm{j})$ catalysts after reduction at $250{ }^{\circ} \mathrm{C}$. 
served in Fig. 3(a), (c), (e), (g), (i), compared with the Pd foil, the oscillation behaviors in the $k$-space of the Pd K-edge were disturbed by $\mathrm{Cu}$ neighbors in all the $\mathrm{Cu}-\mathrm{Pd} / \mathrm{SiO}_{2}$ bimetallic catalysts. In agreement with our previous findings, because of the formation of $\mathrm{Pd}-\mathrm{Cu}$ coordination, the distances between atoms in the first shell of the Pd atoms were obviously shorter than those of the Pd foil (Fig. 3(b), (d), (f), (h), (j)) [31]. The data fitting results of all the $\mathrm{Cu}-\mathrm{Pd} / \mathrm{SiO}_{2}$ catalysts are summarized in Table 2. With decreased $\mathrm{Cu}$ loading, the Pd atoms could be isolated by $\mathrm{Cu}$ in the $\mathrm{Cu}_{40} \mathrm{Pd} / \mathrm{SiO}_{2}$ catalyst, with only $\mathrm{Pd}-\mathrm{Cu}$ coordination existing in this catalyst and a coordination number (CN) of 8.7. Nevertheless, for the $\mathrm{Cu}_{12} \mathrm{Pd} / \mathrm{SiO}_{2}$ catalyst, both $\mathrm{Pd}-\mathrm{Cu}$ and Pd-Pd coordination were observed, with CNs of 8.4 and 1.4, respectively. Further decreasing the $\mathrm{Cu}$ loading induced a decrease of the $\mathrm{Pd}-\mathrm{Cu} \mathrm{CN}$ to 5.0 and an increase of the $\mathrm{Pd}-\mathrm{Pd} \mathrm{CN}$ to 5.9 in the $\mathrm{Cu}_{5} \mathrm{Pd} / \mathrm{SiO}_{2}$ catalyst. Consistent with the TPR results, with decreased $\mathrm{Cu}$ loading, the $\mathrm{Pd}$ in the bimetallic catalysts exhibited behavior similar to that of the monometallic $\mathrm{Pd}$ catalyst. These results indicate that $\mathrm{Cu}$-alloyed Pd SACs can be synthesized with an optimized $\mathrm{Cu} / \mathrm{Pd}$ atomic ratio using the simple wetness co-impregnation method by adjusting the $\mathrm{Cu} / \mathrm{Pd}$ atomic ratio.

The normalized XANES spectra at the Pd K-edge of various $\mathrm{Cu}-\mathrm{Pd} / \mathrm{SiO}_{2}$ bimetallic catalysts reduced at $250{ }^{\circ} \mathrm{C}$ are compared in Fig. 4. Compared with the Pd foil (with an adsorption energy at the $\mathrm{Pd}$ K-edge of $24350.0 \mathrm{eV}$ ), the $\mathrm{Cu}_{160} \mathrm{Pd} / \mathrm{SiO}_{2}$, $\mathrm{Cu}_{40} \mathrm{Pd} / \mathrm{SiO}_{2}, \mathrm{Cu}_{12} \mathrm{Pd} / \mathrm{SiO}_{2}$, and $\mathrm{Cu} 5 \mathrm{Pd} / \mathrm{SiO}_{2}$ catalysts showed adsorption edges of the Pd K-edge at 24348.1, 24348.1, 24348.7, and $24347.4 \mathrm{eV}$, respectively. In agreement with our previous findings, these results indicated that the Pd atoms in these catalysts were negatively charged, which may be attributed to the electron transfer from $\mathrm{Cu}$ to $\mathrm{Pd}$ [31]. This result is reasonable, as the electronegativity of $\mathrm{Cu}$ is lower than that of $\operatorname{Pd}[31,38]$.

\subsubsection{Effects of reduction temperature}

To determine the effects of the reduction temperature on the formation of the Cu-alloyed Pd SACs, XAS experiments were performed over the $\mathrm{Cu}_{12} \mathrm{Pd} / \mathrm{SiO}_{2}$ and $\mathrm{Cu}{ }_{160} \mathrm{Pd} / \mathrm{SiO}_{2}$ catalysts reduced at $400{ }^{\circ} \mathrm{C}$. Based on the EXAFS results in Fig. 5, we know that for reduction at $250{ }^{\circ} \mathrm{C}$, the oscillation behaviors of the $\mathrm{Cu}-\mathrm{Pd} / \mathrm{SiO}_{2}$ bimetallic catalysts in $k$-space differed from that of the Pd foil because of the disturbance caused by the $\mathrm{Cu}$ neighbors (Fig. 5(a), (c), (e)). The formation of the $\mathrm{Cu}-\mathrm{Pd}$ coor-

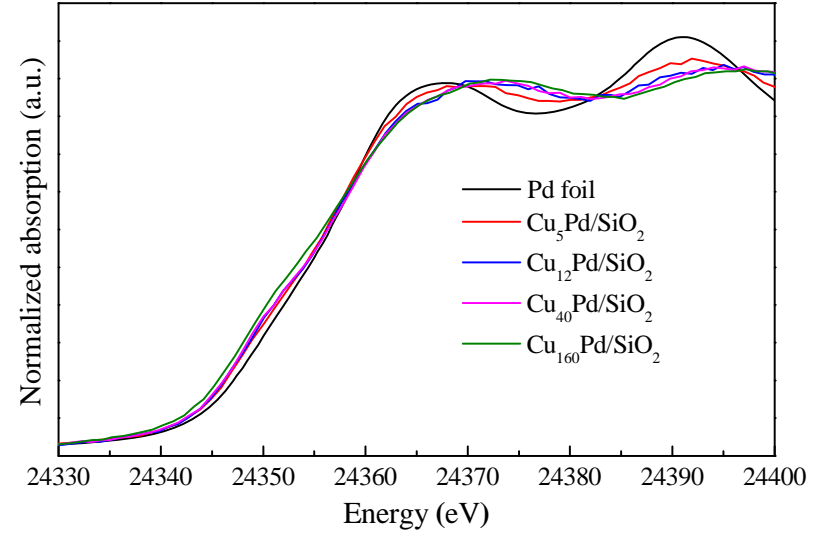

Fig. 4. Normalized XANES spectra at the Pd K-edge of the Pd foil and $\mathrm{Cu}_{5} \mathrm{Pd} / \mathrm{SiO}_{2}, \mathrm{Cu}_{12} \mathrm{Pd} / \mathrm{SiO}_{2}, \mathrm{Cu}_{40} \mathrm{Pd} / \mathrm{SiO}_{2}$, and $\mathrm{Cu}_{160} \mathrm{Pd} / \mathrm{SiO}_{2}$ catalysts after reduction at $250{ }^{\circ} \mathrm{C}$.

dination resulted in a short distance of the first Pd neighbors (Fig. 5(b), (d), (f)). The results in Table 3 also demonstrate that both $\mathrm{Pd}-\mathrm{Cu}$ and $\mathrm{Pd}-\mathrm{Pd}$ coordination were detected in the $\mathrm{Cu}_{12} \mathrm{Pd} / \mathrm{SiO}_{2}$ catalyst with $\mathrm{CNs}$ of 10.4 and 0.9 , respectively. Only $\mathrm{Pd}-\mathrm{Cu}$ coordination was detected in the $\mathrm{Cu}_{160} \mathrm{Pd} / \mathrm{SiO}_{2}$ catalyst, indicating the complete isolation of the $\mathrm{Pd}$ atoms by $\mathrm{Cu}$ in this catalyst, with a $\mathrm{CN}$ of 10.2 . The coordination environments of the $\mathrm{Cu}_{160} \mathrm{Pd} / \mathrm{SiO}_{2}$ and $\mathrm{Cu}_{12} \mathrm{Pd} / \mathrm{SiO}_{2}$ reduced at $400{ }^{\circ} \mathrm{C}$ were similar to those reduced at $250{ }^{\circ} \mathrm{C}$ (Table 2), indicating that increasing the reduction temperature hardly affects the coordination environment of the Pd atoms. This finding differs from that for our $\mathrm{Ag}-\mathrm{Pd} / \mathrm{SiO}_{2}$ system, for which an increased reduction temperature induced restructuring of $\mathrm{Pd}$ and $\mathrm{Ag}$, thereby resulting in better isolation of $\mathrm{Pd}$ atoms [30]. The XANES results in Fig. 6 also indicate that the Pd atoms in all these catalysts were slightly negatively charged, with adsorption energies at the Pd K-edge of 24347.7 and $24348.7 \mathrm{eV}$ for the $\mathrm{CuPd}_{12} / \mathrm{SiO}_{2}$ and $\mathrm{Cu}_{160} \mathrm{Pd} / \mathrm{SiO}_{2}$ catalysts, respectively.

\subsection{Catalytic performance}

Selective hydrogenation of acetylene in an ethylene-rich stream was performed over the as-prepared $\mathrm{Cu}-\mathrm{Pd} / \mathrm{SiO}_{2}$ bimetallic catalysts, and the effects of the $\mathrm{Cu}$ loading and pretreatment temperature were evaluated. First, the catalytic performances of the $\mathrm{Cu}-\mathrm{Pd} / \mathrm{SiO}_{2}$ bimetallic catalysts with different $\mathrm{Cu}$ loadings were analyzed. As observed in Fig. 7(a), after reduction at

Table 2

EXAFS fitting results at $\mathrm{Pd} \mathrm{K}$-edge for the $\mathrm{Pd}$ foil and $\mathrm{Cu}_{5} \mathrm{Pd} / \mathrm{SiO}_{2}, \mathrm{Cu}_{12} \mathrm{Pd} / \mathrm{SiO}_{2}, \mathrm{Cu}_{40} \mathrm{Pd} / \mathrm{SiO}_{2}$, and $\mathrm{Cu}_{160} \mathrm{Pd} / \mathrm{SiO}_{2}$ catalysts reduced at $250{ }^{\circ} \mathrm{C}$.

\begin{tabular}{lcccccccc}
\hline Sample & Shell & \multicolumn{1}{c}{$\mathrm{CN}^{\mathrm{a}}$} & $R(\AA)^{\mathrm{b}}$ & $\sigma^{2} \times 10^{3}\left(\AA^{2}\right)^{\mathrm{c}}$ & $\Delta E_{0}(\mathrm{eV})^{\mathrm{d}}$ & $R$-factor $(\%)$ & $\Delta k\left(\AA^{-1}\right)$ & $\Delta R(\AA)$ \\
\hline $\mathrm{Pd}$ foil & $\mathrm{Pd}-\mathrm{Pd}$ & 12 & 2.74 & 4.8 & 2.1 & 0.19 & $3.0-11.1$ & $1.3-3.4$ \\
$\mathrm{Cu}_{5} \mathrm{Pd} / \mathrm{SiO}_{2}$ & $\mathrm{Pd}-\mathrm{Cu}$ & 5.0 & 2.61 & 7.2 & 2.6 & 0.68 & $3.0-11.1$ & $1.3-3.4$ \\
& $\mathrm{Pd}-\mathrm{Pd}$ & 5.9 & 2.69 & 7.2 & 2.6 & & \\
$\mathrm{Cu}_{12} \mathrm{Pd} / \mathrm{SiO}_{2}$ & $\mathrm{Pd}-\mathrm{Cu}$ & 8.4 & 2.58 & 5.5 & 0.6 & 0.39 & $3.2-11.7$ & $1.4-3.2$ \\
& $\mathrm{Pd}-\mathrm{Pd}$ & 1.4 & 2.64 & 5.5 & 0.6 & & \\
$\mathrm{Cu}_{40} \mathrm{Pd} / \mathrm{SiO}_{2}$ & $\mathrm{Pd}-\mathrm{Cu}$ & 8.7 & 2.55 & 5.3 & -1.8 & 0.98 & $3.0-11.1$ & $1.3-3.4$ \\
$\mathrm{Cu}_{160} \mathrm{Pd} / \mathrm{SiO}_{2}$ & $\mathrm{Pd}-\mathrm{Cu}$ & 11.6 & 2.58 & 6.2 & 2.1 & 0.31 & $3.0-13.1$ & $1.3-3.1$ \\
\hline
\end{tabular}

${ }^{\mathrm{a}} \mathrm{CN}$ for the absorber-backscatterer pair; ${ }^{\mathrm{b}}$ Average absorber-backscatterer distance; ${ }^{\mathrm{c}}$ Debye-Waller factor, ${ }^{\mathrm{d}}$ Inner potential correction. The accuracies of these parameters were estimated as $\mathrm{CN}, \pm 20 \% ; R, \pm 1 \% ; \sigma^{2}, \pm 20 \% ; \Delta E_{0}, \pm 20 \% . \Delta k$ and $\Delta R$ are the data fitting ranges used in $k$-space and $R$-space, respectively. 

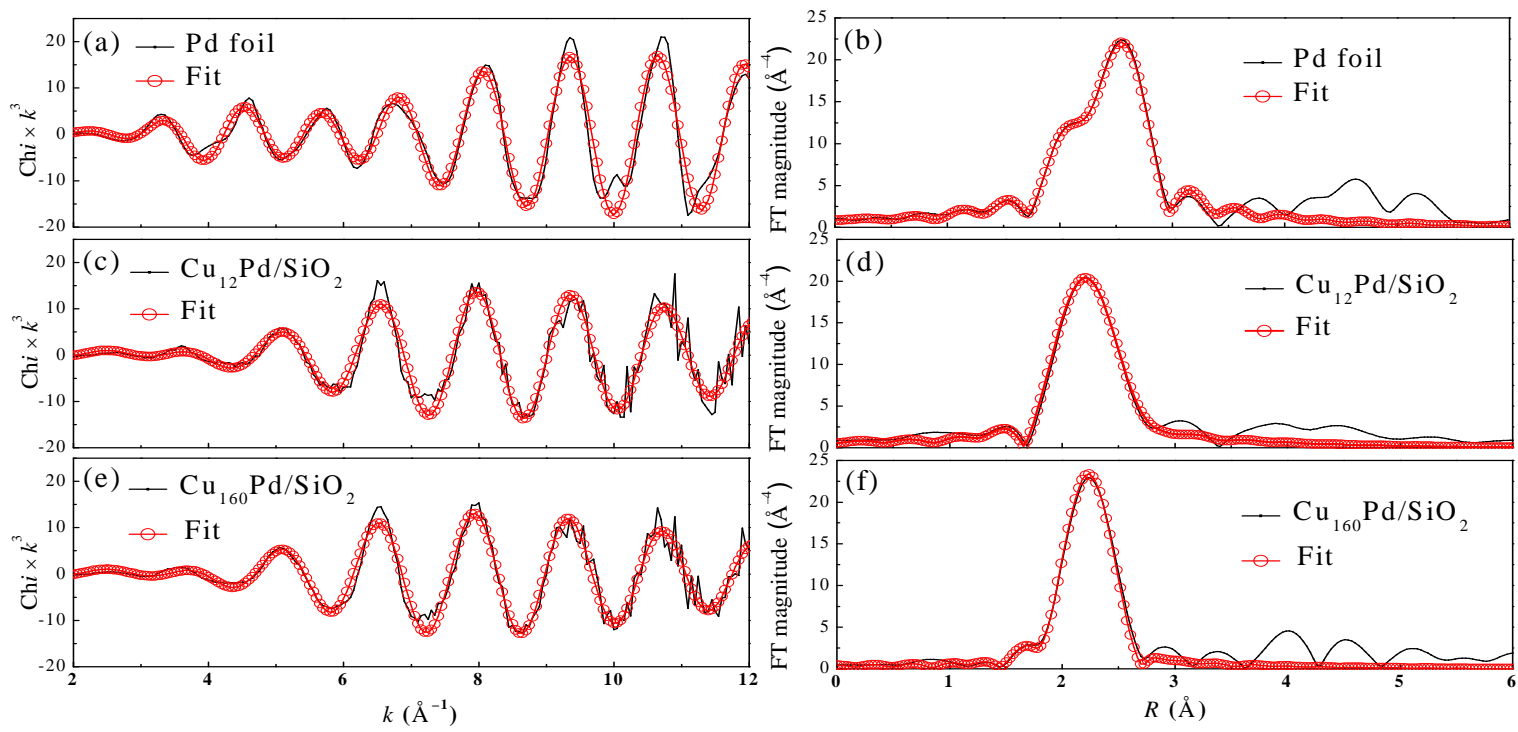

Fig. 5. $k^{3}$-weighted EXAFS spectra in $k$-space (a, c, e) and corresponding Fourier transform spectra in $R$-space (without phase correction) (b, d, f) of the $\mathrm{Pd}$ foil $(\mathrm{a}, \mathrm{b})$ and $\mathrm{Cu}_{12} \mathrm{Pd} / \mathrm{SiO}_{2}(\mathrm{c}, \mathrm{d})$ and $\mathrm{Cu}_{160} \mathrm{Pd} / \mathrm{SiO}_{2}(\mathrm{e}, \mathrm{f})$ catalysts reduced at $400{ }^{\circ} \mathrm{C}$.

Table 3

EXAFS fitting results at $\mathrm{Pd} \mathrm{K}$-edge for the $\mathrm{Pd}$ foil and $\mathrm{Cu}_{12} \mathrm{Pd} / \mathrm{SiO}_{2}$ and $\mathrm{Cu}_{160} \mathrm{Pd} / \mathrm{SiO}_{2}$ catalysts after reduction at $400{ }^{\circ} \mathrm{C}$.

\begin{tabular}{|c|c|c|c|c|c|c|c|c|}
\hline Sample & Shell & $\mathrm{CN}^{\mathrm{a}}$ & $R(\AA ̊)^{\mathrm{b}}$ & $\sigma^{2} \times 10^{3}\left(\AA^{2}\right)^{\mathrm{c}}$ & $\Delta E_{0}(\mathrm{eV})^{\mathrm{d}}$ & $R$-factor $(\%)$ & $\Delta k\left(\AA^{-1}\right)$ & $\Delta R(\AA)$ \\
\hline Pd foil & Pd-Pd & 12 & 2.74 & 4.8 & 2.1 & 0.19 & $3.0-11.1$ & $1.3-3.4$ \\
\hline \multirow[t]{2}{*}{$\mathrm{Cu}_{12} \mathrm{Pd} / \mathrm{SiO}_{2}$} & $\mathrm{Pd}-\mathrm{Cu}$ & 10.4 & 2.58 & 6.1 & 2.6 & 0.59 & $3.0-11.1$ & $1.3-3.4$ \\
\hline & Pd-Pd & 0.9 & 2.71 & 6.1 & 2.6 & & & \\
\hline $\mathrm{Cu}_{160} \mathrm{Pd} / \mathrm{SiO}_{2}$ & $\mathrm{Pd}-\mathrm{Cu}$ & 10.2 & 2.58 & 6.1 & 2.4 & 0.47 & $3.0-13.1$ & $1.3-3.1$ \\
\hline
\end{tabular}

${ }^{\mathrm{a}} \mathrm{CN}$ for the absorber-backscatterer pair; ${ }^{\mathrm{b}}$ Average absorber-backscatterer distance; ${ }^{\mathrm{c}}$ Debye-Waller factor; ${ }^{\mathrm{d}}$ Inner potential correction. The accuracies of these parameters were estimated as CN, $\pm 20 \% ; R, \pm 1 \% ; \sigma^{2}, \pm 20 \% ; \Delta E_{0}, \pm 20 \% . \Delta k$ and $\Delta R$ are the data fitting ranges used in $k$-space and $R$-space, respectively.

$250{ }^{\circ} \mathrm{C}$, the $\mathrm{Cu}-\mathrm{Pd} / \mathrm{SiO}_{2}$ bimetallic catalyst with a $\mathrm{Cu} / \mathrm{Pd}$ atomic ratio of 5/1 exhibited high acetylene conversion at low temperatures. The conversion reached $100 \%$ at $80{ }^{\circ} \mathrm{C}$, and the corresponding selectivity to ethylene was approximately $-300 \%$ (the selectivity greatly decreased with increasing reaction temperature) (Fig. 7(b)). This finding is consistent with most of the previous results, which indicate that a large amount of ethylene in the feedstock is hydrogenated to ethane $[39,40]$. With increased $\mathrm{Cu}$ loading, the temperature needed to achieve complete acetylene conversion also increased (Fig. 7(a)). However, the corresponding ethylene selectivity also clearly increased (Fig. 7(b)). The $\mathrm{Cu}_{12} \mathrm{Pd} / \mathrm{SiO}_{2}$ catalyst displayed $>60 \%$ ethylene selectivity at $100 \%$ acetylene conversion. The $\mathrm{Cu}_{40} \mathrm{Pd} / \mathrm{SiO}_{2}$ and $\mathrm{Cu}_{160} \mathrm{Pd} / \mathrm{SiO}_{2}$ catalysts displayed similar ethylene selectivity at $160{ }^{\circ} \mathrm{C}$, all of which were improved by $>650 \%$ compared with that of the $\mathrm{Cu}_{5} \mathrm{Pd} / \mathrm{SiO}_{2}$ catalyst, indicating that the isolation of $\mathrm{Pd}$ atoms significantly contributed to the enhanced ethylene selectivity. Upon increasing the reaction temperature to $240{ }^{\circ} \mathrm{C}$, the acetylene conversion remained at $100 \%$; however, the ethylene selectivity showed some differences, which may be attributed to the different positions of Pd atoms on Cu nanoparticles. This behavior was also reported by Zhu et al. [41,42] who showed that Pd atoms on different sites of the particles may contribute differently to the catalytic performance.

After the catalysts were reduced at $400{ }^{\circ} \mathrm{C}$, we evaluated the catalytic performance of the $\mathrm{Cu}_{12} \mathrm{Pd} / \mathrm{SiO}_{2}$ and $\mathrm{Cu}_{160} \mathrm{Pd} / \mathrm{SiO}_{2}$ catalysts for the semi-hydrogenation of acetylene in an eth- ylene-rich stream and compared the results with those of the catalysts reduced at $250{ }^{\circ} \mathrm{C}$. As observed in Fig. 8, after the reduction pretreatment at $400{ }^{\circ} \mathrm{C}$, the acetylene conversion and ethylene selectivity showed similar behaviors as those of the catalysts reduced at $250{ }^{\circ} \mathrm{C}$. These results indicate that the catalytic performance of the $\mathrm{Cu}-\mathrm{Pd} / \mathrm{SiO}_{2}$ bimetallic system is not as sensitive to the reduction temperature as the $\mathrm{Ag}-\mathrm{Pd}$ system [30]. This finding can be attributed to the insensitive restructuring of $\mathrm{Cu}$ and $\mathrm{Pd}$ atoms against varied reduction temperatures and is consistent with the EXAFS fitting results, which indicated that with increased reduction temperature, the

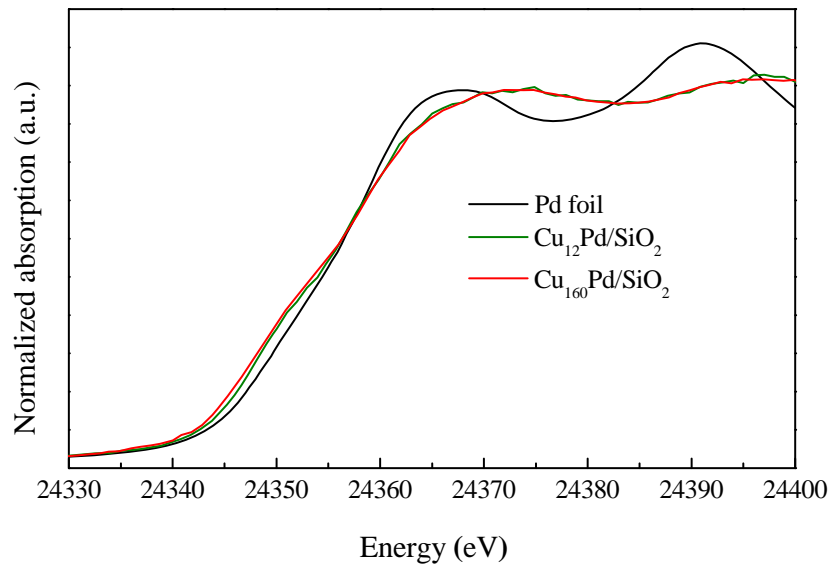

Fig. 6. Normalized XANES spectra at Pd K-edge of the Pd foil and $\mathrm{Cu}_{12} \mathrm{Pd} / \mathrm{SiO}_{2}$ and $\mathrm{Cu}_{160} \mathrm{Pd} / \mathrm{SiO}_{2}$ catalysts after reduction at $400{ }^{\circ} \mathrm{C}$. 

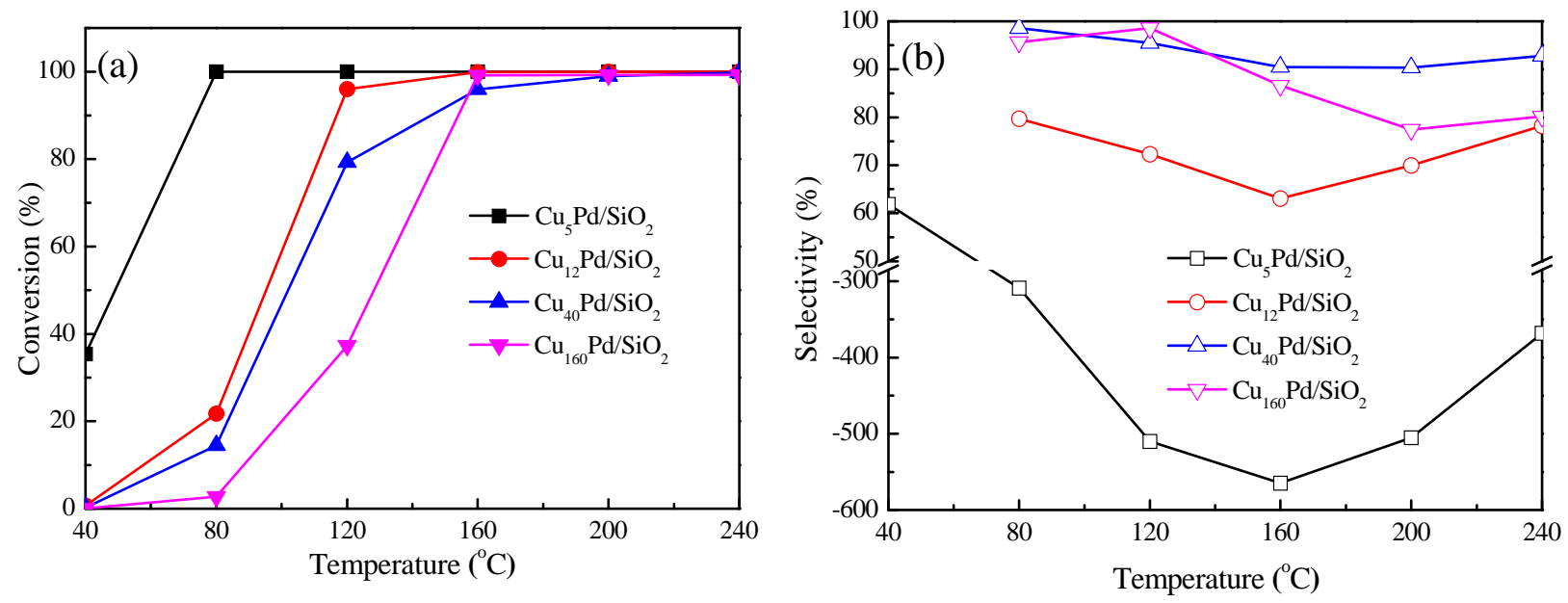

Fig. 7. Acetylene conversion (a) and ethylene selectivity (b) with increased reaction temperature over the $\mathrm{Cu}_{160} \mathrm{Pd} / \mathrm{SiO}_{2}, \mathrm{Cu}_{40} \mathrm{Pd} / \mathrm{SiO}_{2}, \mathrm{Cu}_{12} \mathrm{Pd} / \mathrm{SiO}{ }_{2}$, and $\mathrm{Cu}_{5} \mathrm{Pd} / \mathrm{SiO}_{2}$ catalysts after reduction at $250^{\circ} \mathrm{C}$.
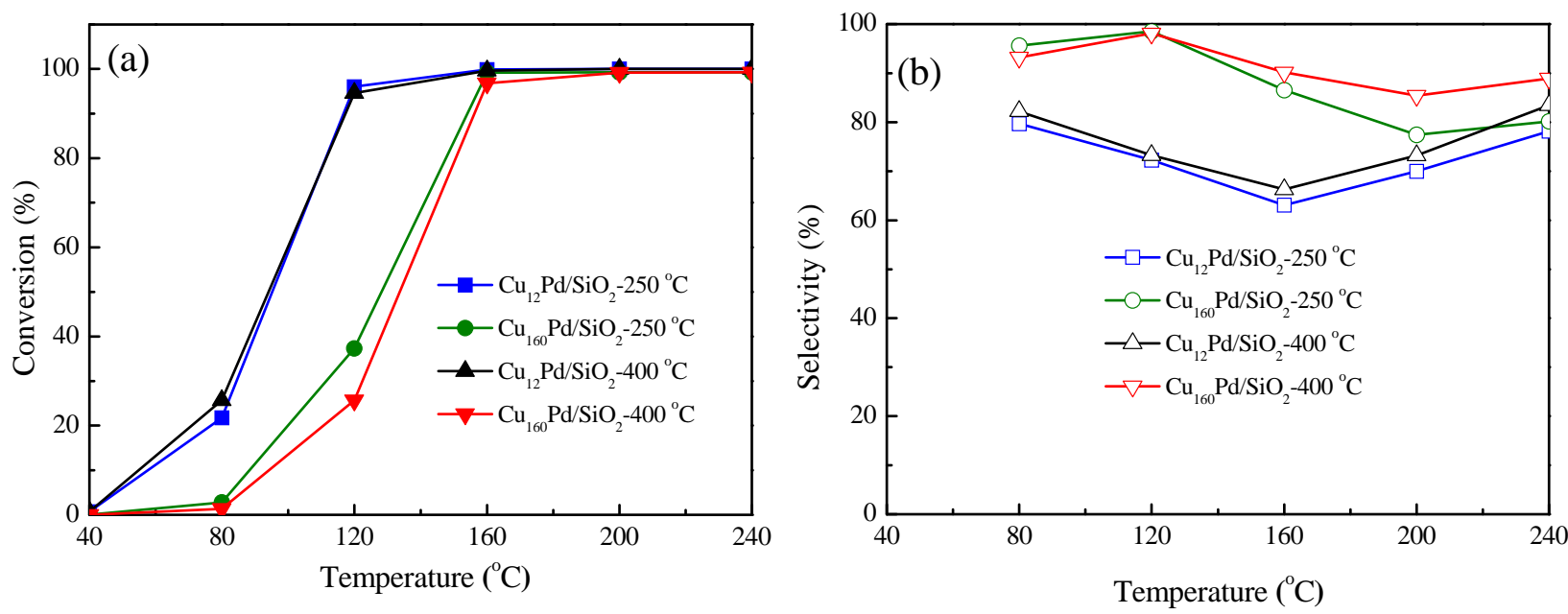

Fig. 8. Acetylene conversion (a) and ethylene selectivity (b) with increased reaction temperature over the $\mathrm{Cu}_{12} \mathrm{Pd} / \mathrm{SiO}_{2}$ and $\mathrm{Cu}{ }_{160} \mathrm{Pd} / \mathrm{SiO}_{2}$ catalysts after reduction at 250 and $400{ }^{\circ} \mathrm{C}$.

chemical environment of the Pd atoms was hardly disturbed in the $\mathrm{Cu}_{12} \mathrm{Pd} / \mathrm{SiO}_{2}$ and $\mathrm{Cu}_{160} \mathrm{Pd} / \mathrm{SiO}_{2}$ catalysts (Table 2 and Table 3).

\section{Conclusions}

Cu-alloyed Pd SACs with varied $\mathrm{Cu}$ loadings were synthesized using an incipient wetness co-impregnation method. Decreased $\mathrm{Cu}$ loading resulted in smaller $\mathrm{Cu}-\mathrm{Pd}$ bimetallic particle sizes. The formation of the $\mathrm{Cu}-\mathrm{Pd}$ bimetallic catalyst induced facile reduction of the catalysts. The optimized $\mathrm{Cu}$ and $\mathrm{Pd}$ loadings can be used for the synthesis of Cu-alloyed Pd SACs, which will contribute to enhanced catalytic performance as well as efficient use of both metals. Upon increasing the reduction temperature from 250 to $400{ }^{\circ} \mathrm{C}$, the chemical environment of Pd was hardly changed, as demonstrated by XAS analysis. Thus, the catalytic performances of the $\mathrm{Cu}-\mathrm{Pd} / \mathrm{SiO}_{2}$ catalysts were not as sensitive to the reduction pretreatment as those of $\mathrm{Pd}-\mathrm{Ag} / \mathrm{SiO}_{2}$ catalysts. This study will inspire the design of other alloyed SACs to achieve excellent catalytic performance for selective hydrogenation reactions.

\section{Acknowledgments}

The authors are grateful to the BL $14 \mathrm{~W}$ at the Shanghai Synchrotron Radiation Facility (SSRF) for the XAFS experiments.

\section{References}

[1] B. T. Qiao, A. Q. Wang, X. F. Yang, L. F. Allard, Z. Jiang, Y. T. Cui, J. Y. Liu, J. Li, T. Zhang, Nat. Chem., 2011, 3, 634-641.

[2] X. F. Yang, A. Q. Wang, B. T. Qiao, J. Li, J. Y. Liu, T. Zhang, Acc. Chem. Res., 2013, 46, 1740-1748.

[3] J. Lin, A. Q. Wang, B. T. Qiao, X. Y. Liu, X. F. Yang, X. D. Wang, J. Liang, J. Li, J. Y. Liu, T. Zhang, J. Am. Chem. Soc., 2013, 135, 15314-15317.

[4] H. S. Wei, X. Y. Liu, A. Q. Wang, L. L. Zhang, B. T. Qiao, X. F. Yang, Y. Q. Huang, S. Miao, J. Y. Liu, T. Zhang, Nat. Commun., 2014, 5, 5634.

[5] M. Yang, S. Li, Y. Wang, J. A. Herron, Y. Xu, L. F. Allard, S. Lee, J. Huang, M. Mavrikakis, M. Flytzani-Stephanopoulos, Science, 2014, 346, 1498-1501. 
[6] W. Liu, L. Zhang, W. Yan, X. Liu, X. Yang, S. Miao, W. Wang, A. Wang, T. Zhang, Chem. Sci., 2016, 7, 5758-5764.

[7] B. Qiao, J. X. Liang, A. Wang, J. Liu, T. Zhang, Chin. J. Catal., 2016, 37, 1580-1586.

[8] J. Jones, H. Xiong, A. T. DeLaRiva, E. J. Peterson, H. Pham, S. R. Challa, G. Qi, S. Oh, M. H. Wiebenga, X. I. Pereira. Hernández, Y. Wang, A. K. Datye, Science, 2016, 353, 150-154.

[9] J. C. Matsubu, V. N. Yang, P. J. Christopher, J. Am. Chem. Soc., 2015, 137, 3076-3084.

[10] G. Kyriakou, M. B. Boucher, A. D. Jewell, E. A. Lewis, T. J. Lawton, A. E. Baber, H. L. Tierney, E. C. H. Sykes, M. Flytzani-Stephanopoulos, Science, 2012, 335, 1209-1212.

[11] M. B. Boucher, B. Zugic, G. Cladaras, J. Kammert, M. D. Marcinkowski, T. J. Lawton, E. C. H. Sykes, M. Flytzani-Stephanopoulos, Phys. Chem. Chem. Phys., 2013, 15, 12187-12196.

[12] F. R. Lucci, J. Liu, M. D. Marcinkowski, M. Yang, L. F. Allard, M. Flytzani-Stephanopoulos, E. C. H. Sykes, Nat. Commun., 2015, 6, 8550.

[13] H. J. Zhang, T. Watanabe, M. Okumura, M. Haruta, N. Toshima, Nat. Mater., 2012, 11, 49-52.

[14] H. J. Zhang, K. Kawashima, M. Okumura, N. Toshima, J. Mater. Chem. A, 2014, 2, 13498-13508.

[15] L. Zhang, A. Wang, J. T. Miller, X. Liu, X. Yang, W. Wang, L. Li, Y. Huang, C. Y. Mou, T. Zhang, ACS Catal, 2014, 4, 1546-1553.

[16] M. M. Johnson, D. W. Walker, G. P. Nowack, US Patent 4404124, 1983.

[17] M. R. Rahimpour, O. Dehghani, M. R. Gholipour, M. S. Shokrollahi Yancheshmeh, S. Seifzadeh Haghighi, A. Shariati, Chem. Eng. J., 2012, 198-199, 491-502.

[18] H. Zhou, X. Yang, L. Li, X. Liu, Y. Huang, X. Pan, A. Wang, J. Li, T.
Zhang, ACS Catal. 2016, 6, 1054-1061.

[19] H. Zhou, X. Yang, A. Wang, S. Miao, X. Liu, X. Pan, Y. Su, L. Li, Y. Tan, T. Zhang, Chin. J. Catal., 2016, 37, 692-699.

[20] J. M. Moses, A. H. Weiss, K. Matusek, L. Guczi, J. Catal., 1984, 86, 417-426.

[21] A. Borodziński, G. C. Bond, Catal. Rev. Sci. Eng., 2008, 50, 379-469.

[22] W. J. Kim, S. H. Moon, Catal. Today, 2012, 185, 2-16.

[23] Y. Han, D. Peng, Z. Xu, H. Wan, S. Zheng, D. Zhu, Chem. Commun., 2013, 49, 8350-8352.

[24] A. J. McCue, A. M. Shepherd, J. A. Anderson, Catal. Sci. Technol., 2015, 5, 2880-2890.

[25] C. Ma, Y. Du, J. Feng, X. Cao, J. Yang, D. Li, J. Catal., 2014, 317, 263-271.

[26] M. Armbrüster, G. Wowsnick, M. Friedrich, M. Heggen, R. Cardoso-Gil, J. Am. Chem. Soc., 2011, 133, 9112-9118.

[27] D. Teschner, J. Borsodi, A. Wootsch, Z. Révay, M. Hävecker, A. Knop-Gericke, S. D. Jackson, R. Schlögl, Science, 2008, 320, 86-89.

[28] A. J. McCue, A. Guerrero-Ruiz, I. Rodríguez-Ramos, J. A. Anderson, J. Catal., 2016, 340, 10-16.

[29] G. X. Pei, X. Y. Liu, A. Q. Wang, L. Li, Y. Huang, T. Zhang, J. W. Lee, B. W. L. Jang, C. Y. Mou, New J. Chem., 2014, 38, 2043-2051.

[30] G. X. Pei, X. Y. Liu, A. Wang, A. F. Lee, M. A. Isaacs, L. Li, X. Pan, X. Yang, X. Wang, Z. Tai, K. Wilson, T. Zhang, ACS Catal., 2015, 5, 3717-3725.

[31] G. X. Pei, X. Y. Liu, X. Yang, L. Zhang, A. Wang, L. Li, H. Wang, X. Wang, T. Zhang, ACS Catal., 2017, 5, 1491-1500.

[32] H. S. Yu, X. J. Wei, J. Li, S. Q. Gu, S. Zhang, L. H. Wang, J. Y. Ma, L. N. Li, Q. Gao, R. Si, F. F. Sun, Y. Wang, F. Song, H. J. Xu, X. H Yu, Y. Zou, J. Q. Wang, Z. Jiang, Y. Y. Huang, Nucl. Sci. Tech., 2015, 26, 050102.

[33] X. Liu, C. Y. Mou, S. Lee, Y. Li, J. Secrest, B. W. L. Jang, J. Catal., 2012, 285, 152-159.

\section{Graphical Abstract}

Chin. J. Catal., 2017, 38: 1540-1548 doi: 10.1016/S1872-2067(17)62847-X

Isolation of Pd atoms by $\mathrm{Cu}$ for semi-hydrogenation of acetylene: Effects of $\mathrm{Cu}$ loading

Guangxian Pei, Xiaoyan Liu*, Mengqian Chai, Aiqin Wang, Tao Zhang*

Dalian Institute of Chemical Physics, Chinese Academy of Sciences; University of Chinese Academy of Sciences

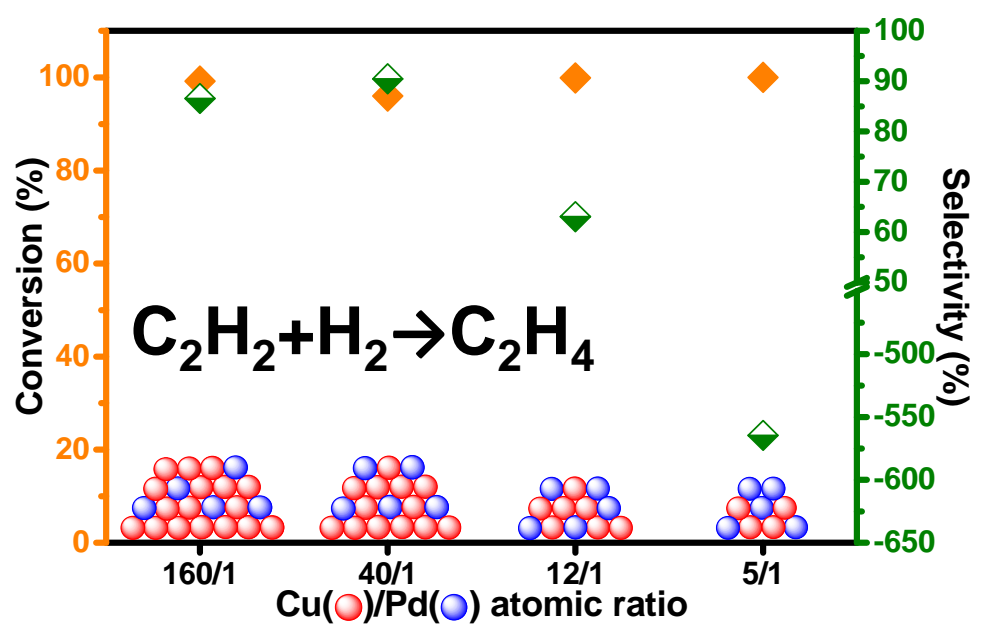

Cu-alloyed Pd single-atom catalysts were formed for $\mathrm{Cu} / \mathrm{Pd}$ atomic ratios $\geq 40 / 1$ and displayed excellent catalytic performance for the semi-hydrogenation of acetylene in excess ethylene. 
[34] X. Liu, Y. Li, J. W. Lee, C. Y. Hong, C. Y. Mou, B. W. L. Jang, Appl. Catal. A, 2012, 439-440, 8-14.

[35] J. W. Lee, X. Liu, C. Y. Mou, J. Chin. Chem. Soc., 2013, 60, 907-914.

[36] I. Y. Ahn, W. J. Kim, S. H. Moon, Appl. Catal. A, 2011, 308, 75-81.

[37] Q. Zheng, M. D. Wales, M. G. Heidlage, M. Rezac, H. Wang, S. H. Bossmann, K. Hohn, J. Catal., 2015, 330, 222-237.

[38] R. E. Dickerson, H. B. Gray, G. P. Haight, Chemical Principles, 3rd edition, Benjamin/Cummings Publishing, 1979.
[39] Y. Jin, A. K. Datye, E. Rightor, R. Gulotty, W. Waterman, M. Smith, M. Holbrook, J. Maj, J. Blacksony, J. Catal., 2001, 203, 292-306.

[40] S. K. Kim, J. H. Lee, I. Y. Ahn, W. J. Kim, S. H. Moon, Appl. Catal. A, 2011, 401, 12-19.

[41] B. Zhu, G. Thrimurthulu, L. Delannoy, C. Louis, C. Mottet, J. Creuze, B. Legrand, H. Guesmi, J. Catal., 2013, 308, 272-281.

[42] M. Crespo-Quesada, A. Yarulin, M. Jin, Y. Xia, L. Kiwi-Minsker, J. Am. Chem. Soc., 2011, 133, 12787-12794.

\title{
Cu分隔开的Pd单原子用于乙炔选择加氢: Cu担载量的影响
}

\author{
裴广贤 ${ }^{\mathrm{a}, \mathrm{b}}$, 刘晓艳 ${ }^{\mathrm{a}, *}$, 柴梦倩 $\mathrm{a,b}$, 王爱琴 ${ }^{\mathrm{a}}$, 张 涛, ${ }^{\mathrm{a}, \#}$ \\ a中国科学院大连化学物理研究所, 辽宁大连116023

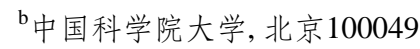

摘要: 大量乙烯中少量乙炔的去除是化工生产中的重要过程之一, 理想途径是将其选择加氢生成乙烯. 负载型Pd催化剂因 具有很高的乙炔转化率而被广泛用于该过程, 但乙烯选择性很低, 同时会使原料气中的乙烯被加氢, 造成原料气的浪费. 采用其它元素对Pd纳米粒子表面修饰, 覆盖部分活性位, 可以在一定程度上提高乙烯选择性, 但是会大大降低Pd的利用率. 因此, 制备兼具高活性和高选择性且经济实用的催化剂, 仍是这一过程亟待解决的主要问题之一. 我们的前期工作中, 将 $\mathrm{Pd}$ 与 IB族金属 $(\mathrm{Au}, \mathrm{Ag}, \mathrm{Cu})$ 分别结合制备得到了一系列含Pd的合金单原子催化剂(SAC), 发现它们在大量乙烯存在条件下 的乙炔选择加氢反应中表现出优异的催化性能. 其中, Pd的用量仅为ppm级别, 大大提高了 Pd的利用率. 作为IB族最为廉 价的金属, $\mathrm{Pd}$ 与 $\mathrm{Cu}$ 形成的合金 SAC在提高Pd原子利用率的同时, 能够进一步降低催化剂的经济成本. 然而, 当形成合金 $\mathrm{SAC}$ 时, $\mathrm{Cu} / \mathrm{Pd}$ 原子比例的极限值仍然不确定.

本文通过固定Pd的担载量, 采用简单的等体积共浸渍的方法, 制备了一系列不同 $\mathrm{Cu} / \mathrm{Pd}$ 原子比例的氧化硅负载的双金 属催化剂. 首先, 我们采用程序升温还原(TPR)和X射线衍射(XRD)对催化剂的还原能力和双金属纳米粒子的尺寸进行了 考察. 进一步, 采用X射线吸收光谱(XAS, 包括EXAFS和XANES)对双金属催化剂中Pd的配位环境进行了分析. 最后, 结合 它们在大量乙烯存在条件下的乙炔选择加氢反应中的催化性能, 对形成合金SAC时Cu/Pd原子比例进行了讨论.

TPR结果显示, $\mathrm{Cu}$ 与 Pd结合时会促进双金属纳米粒子的还原. XRD结果表明, 随着Cu含量的降低, 双金属纳米粒子的 尺寸明显减小. XANES结果证实, 当Pd与 $\mathrm{Cu}$ 结合时, $\mathrm{Pd}$ 会带有部分负电荷, 这也与 $\mathrm{Pd}$ 的电负性大于 $\mathrm{Cu}$ 相一致. 通过对 EXAFS拟合结果进行分析, 我们发现当 $\mathrm{Cu} / \mathrm{Pd}$ 的原子比例 $\geq 40 / 1$ 时, $\mathrm{Pd}$ 原子可以被Cu原子完全分隔开, 形成含Pd的合金SAC, 使其在大量乙烯存在条件下的乙炔选择加氢反应中表现出优异的催化性能. 通过对还原温度的考察, 我们发现还原温度 由 $250{ }^{\circ} \mathrm{C}$ 升高到 $400{ }^{\circ} \mathrm{C}$ 时, 对同一催化剂的催化性能影响不大; EXAFS拟合结果显示, 对比分别经过 250 和 $400{ }^{\circ} \mathrm{C}$ 还原后的 催化剂, Pd的配位环境变化不明显, 这可能是导致催化性能相似的主要原因.

关键词: 铜; 钯; 单原子催化剂; X射线吸收光谱; 乙炔加氢; 大量乙烯

收稿日期: 2017-03-31. 接受日期: 2017-04-30. 出版日期: 2017-09-05.

*通讯联系人. 电话: (0411) 84379416; 传真: (0411) 84685940; 电子信箱: xyliu2003@dicp.ac.cn

\#通讯联系人. 电话: (0411) 84379015; 传真: (0411) 84691570; 电子信箱: taozhang@dicp.ac.cn

基金来源：国家自然科学基金(21303194, 21476227, 21522608, 21690084); 中国科学院青年促进会(2014163); 科技部国家重点研 发计划“纳米科技”重点专项(2016YFA0202801); 中科院战略性先导科技专项(XDB17020100); 辽宁省科技部(2015020086-101). 本文的英文电子版由Elsevier出版社在ScienceDirect上出版(http://www.sciencedirect.com/science/journal/18722067). 